SEICHE IN PORTS

\author{
1.S. Apte ${ }^{1}$ \\ Gentral Fater and Powror Resercch Stution, Poona, India \\ and \\ C. Isorcon
}

Ingóniear ma laboratoires de Mécanique des Fluide日

de I"Ecole Nationale Supérieure d'Electrotechntque et d'Hydreulique de Grevioble (France)

In his thesis Prof. John S. Mellown has given on account of experiments on sefche in port models. Though the fundemental canes of selch in harbours and ports are more or less knom, we have little knowledge of the harbour dimensions for which a perticular selche 1o likely to occur. A systematic stady was therefore initiated by Prof. Kollown and our work dencribed in this peper ma be considered as its contimation.

We shall recall briefly the eesential elemats of Prof. Mollown's rork.

He considered port models with arizontal bottom and vertical walls; the ports had a narres entranos through which waven coming frem the sea pentrated. The porte wre of geometrically idealized form - sgaare and circle - and were placed inside a weve-besin, alao with a horizontal bottcm (fIg. 1). Oatside the port and in the picinity of the entrence, fine gravel was deposited forming an absorbing beach to avoid reflections. The incoming wave from the sea was normal to the pase.

In this model Prof. Mollom sought to describe both expe rimentally and theoretioally, the agitation inaide the port as a fanction of the conditions in the open sea cuteide. He considered a regular train of waves coming towarde the entramse of the port and be wade the simplyfying hypothesis that the wave-crest continues to be uniform at the section of entrance. Bat becenve of the reflection ineide the port a clapotio is formed in the immediate vicinity of the entrance.

Two types of motion mere observed insids the port. In the first, called the resonent motion, the peried of the generating wave coincides with a characterietic period a the port regarded as a closed bacin. In this case,

1 it present at Imboratolre de Yécanique des Maides de I'Inotitat Poly technique, Grenoble, France. 
86 might be expected, there were no appreciable normal volocities at the entrance section. In the seconi type of motion, the non-resonent, the normal velocity at the entrance is not zero and forms an integral part of the internal motion. Mallown was able to realize experimentally certafn charactoriotic resonant movements. On the basis of the hypothe is of clapotis mentioned in the preceeding paragreph be postulated that in every case when the period of the seamrave is equal to a characteristio period of the port, resonont motion onsues.

\section{THEORY OF THE PHENONGIK}

Prefa. Kravtchenke and Mollown have given a theoretical account of this phenomenon. With axes of reference Ozyz - axis Oz verticelly upwards and 0 g in the plane of man mater level inside the part - the velocity potential of motion in the port can be vritton as :

$$
\phi(x, y, z, t)=A \sin \frac{2 \pi}{T} t \frac{\operatorname{ch}\{k(z+h)\}}{c h k h} F(x, y) \text {, }
$$

where $I$ is the period of the generating wave, $h$ is the depth of water, 1 a coratant and $F(x, y)$ matiofien the differential equation :

$$
\Delta F+k^{2} F=0
$$

$k$ is related to the peried by the equation :

$$
\left(\frac{2 \pi}{T}\right)^{2}=g k t h(k h) \text {. }
$$

In addition to (2), F astiafies the condition:

$$
\frac{d F}{d n}=0
$$

along the vertical welle of the port, where $a$ is the direction of the normal. to the boondery of the port. Llong the pert of the boandary occupied by the entrance we mite, on the basis of the clepotis:

$$
\frac{d F}{d n}=B
$$


$B$ being a constant. Evidently wo may generalize the problem by taking the right-hand alde of (5) to represent a variable function instead of a constant. Such generalized problem presenta almost inouparable difficalt1es both for the theoretical solution and its experimental realization.

The constant $B$ in equation (5) is determined by the clapotis outaide the port ; the equation (5) expresses the fact that at the entrance the normal velocity depends only on the coordi nate $z$. 1 resonent movement is a consequence of zero normal velocity, i.e. $B=0$. In the gere ral case, the value of $B$ will have to be determined experimentally.

\section{ITMITATION OF MaNOWN'S EXPERDMENTS}

The hypothesis of clapotis was found to be in good accord $\mathrm{W}$ th the experiments performed by McNown. However there are limitations to both the theoretical and physical aspects of these experiments which were recognized by Prof. McNown himself.

For the hypothesis of clapotis to be approxinately correct, the width of the ontrance to the port should be all ; this will become evident if one considers the profile of the water-surface at the entrance. If the lovel of the water-surface across the entrance is to follow that of a clapotis outside the port, the water surface will be approximately a horizontal straight line. Such would definitely not be the case if, for instance, a nodal line of the resonant motion inside the port were to end on the entrance. Nor mast a nodal line terminate at a point near the section of entrance. It is interesting to see that in the cases of resonant motion oxamined experimentally by $\mathrm{McN}$ om, the nodal lines were considerably aray from the entrance section.

There is yet another difficul ty in the fornulation of the theory, where the hypothesis of a clapotis, so attractively aimple as it is, leads to a contradiction. The potential function for the region occupied by the port wich is the potential of a resonant motion and the potential function outside the port which represents a clapotis do not represent the same function, which they should, since the wave-basin and the port are parts of a region described by the analytic contimation of a hamonic function.

Profs. Kravtchenko and McNom have recognized this difficulty and have remarked that the theory can be applied as a first approximation only to ports having narrow entrances. Under such circumstances the deviation of the free surface profile fram a horizontal straight line can be neglected in the section of entrance. Te have alrea of seen, horrever, that this approximation even ceases to be valid when there is a nodal line terminating on the entrance. 
Table I. Period in seconds.

\begin{tabular}{|l|rrrrrrrrr|}
\hline$n_{m}$ & 0 & 1 & 2 & 3 & 4 & 5 & 6 & 8 & 8 \\
\hline 0 & & & & 1.319 & 1.063 & 0.916 & 0.819 & 0.750 & 0.698 \\
1 & & & 1.718 & 1.277 & 1.046 & 0.907 & 0.817 & 0.747 & 0.695 \\
2 & & & 1.451 & 1.176 & 1.0 & 1,882 & 0.799 & 0.738 & 0.689 \\
3 & 1.460 & 1.382 & 1.220 & 1.063 & 0.940 & 0.848 & 0.778 & 0.723 & 0.679 \\
4 & 1.164 & 1.131 & 1.053 & 0.962 & 0.879 & 0.810 & 0.752 & 0.705 & \\
5 & 0.994 & 0.977 & 0.934 & 0.879 & 0.823 & 0.771 & 0.725 & & \\
6 & 0.883 & 0.874 & 0.848 & 0.812 & 0.773 & 0.734 & & & \\
7 & 0.805 & 0.799 & 0.783 & 0.758 & 0.730 & & & & \\
8 & 0.747 & 0.734 & 0.731 & 0.714 & & & & & \\
\hline
\end{tabular}

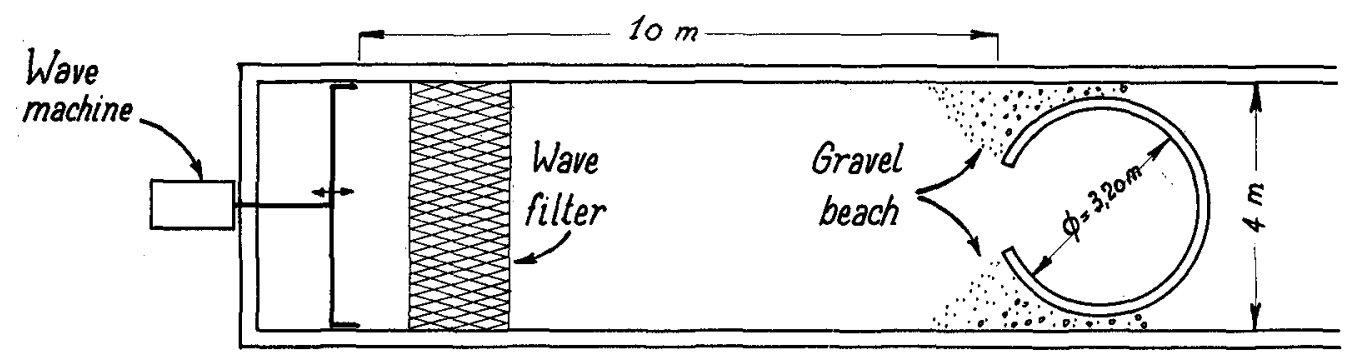

Fig. 1. Port model used by Professor McNown.

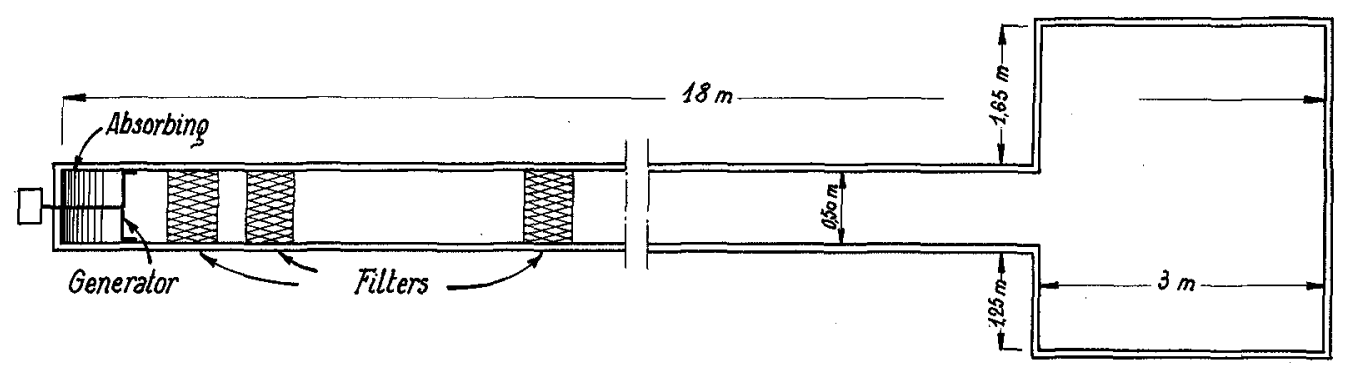

Fig. 2. Port model at the hydraulics laboratory Institut Polytechnique, Grenoble. 
It appeared to us that these were the reasons at the origin of certain anomalies noted by Prof. Mellown. Considering the practical impartance of seiche In the theory of harbour design, it wes thought desirable to extend the resalts of Prof. MaNown's work, eliminating at the same tim the rather restrictive hypotheses he made.

It is the object of this artiole to describe the experimente and the theoretical andysis oarried out starting from Mcllon's initial experiments. our researcbes are not jot complete, though, wo believe thet the disarepancies observed by Prof. Mollow have been explained and in part removed. We have attempted to give here the present state of our investigation ; fer simplicity the following exposition will be restricted exclusively to resonent movements in ports.

We mey state the goneral conclusione of our experiments is a ftrat approximation the theory developed by Mcliom gives an excellent interprotation of the phenomenon observed in the laboratory for a large band of periods, with the reservation that the width of the entrance is anall with respeot to the dimensions of the port. The theory needs modification when the latter reatriotion is no longer valid or when a nodal line of the resonent movemont terminates on the entrance. In either oase the exiltence of a resonant movement io not affected, only the hypothesis of the olapetie is no longer applicablo.

\section{DESCRIPMION OF THE HODEL : EXPERTMATIL RESUITS}

Wa used a rectengular port of width $3.40 \mathrm{~m}$, length $3 \mathrm{~m}$; the depth could be varied from $30 \mathrm{~cm}$ to $40 \mathrm{~cm}$. There was, however, on important difference in our model from the one stadied by Prof. MeKom : whereas his model was placed in a mave-beain, cours wes situated at the end of a wave-canal ( $\mathrm{fig}_{\mathrm{g}} 2$ ). Wo chowe rather artifidal conditions, alnce it was our objeotive to have as pure an incident wave as posatble. The canal wer not aymotrito with respeot to the port ; however thie does not osmese appreoiable diesgmetry in the agitation observed inatie the part. It the other ond of the canal, at a distenos of 15 in from the port, was pleced the wave generator.

With this arrangement a wide range of frequencios was investigated for resonant movenents. For all characteristic periods a selobe was observed in the port, excepting a very suall mumer of cases, the ressons of which are still under stady. In the ir article referred to below, Profs. Kravtahenko and Mollown have obtai nod an analjtioal condition whioh allowe a solution more genoral them a simple resonet movenent, when the corresponding period is a characteristic period of the resonent movenent. The condition bas not yet boen verifiod experimentelly. 
For resonent movement the free-earface instde the port is given by the expreasion :

$$
\eta=A \cos \frac{m \pi x}{a} \cos \frac{m \pi y}{b}
$$

where and $b$ are used to denote the lengths of sides of the rectangalar port, and $\mathbf{n}, \mathbf{n}$ denote the number of nodal linas parallel to each alde. farmale:

The characterietic values of $k$ in equation (2) are given by the

$$
k_{m, n}=\pi\left(\frac{m^{2}}{a^{2}}+\frac{n^{2}}{b^{2}}\right)^{1 / 2} .
$$

The depth or water in cour experimente was kept at $30 \mathrm{~cm}$. The table at the ond gives the charecteristic periods investigated; the period $\mathrm{Im}, \mathrm{n}$ mas calculated by moans of equations (3) and ( 7 ) on substituting $h=0.3$.

In the entrance of the port the emplitade of oscillation of the water curface is known from (6):

$$
\eta_{m, n}(x, 0)=A \cos \frac{m \pi x}{a}
$$

where $x$ varies between $x_{1}, x_{2}$ the absctesen of the extremities of the ontranoe. Thus if is small and if a zero of $\cos m i x / a$ does not fall between $x_{1}, x_{2}=y$ approximate the profile by a atraight line. This presupposes naturally that the width of the entrance is andil as coupared to the length of the side of the port. More precisely, Mollown's hrpothesis is valid then the section of ontrame contains a maximom (and a mintman) value of the rmotion (8).

When is 1 ixge, $\cos m \pi x / a$ in (8) has on or more zeros between $x_{1}, x_{2}$, denoting so way nodal lines terminating on the section of entrance. Even then wo have observed, hourver, that the resonant phanomenon persiste ; In fact the amplitade of oecillation inside the port being much greater than that in the wave-canal, the movement in the latter is altered considerably at least for some distance (4 m.approximately) from the section of entrance.

Int ws cite, fur illustration, a fer resonmat cases from the Table of periods. For the movement denoted by $=5, n=0$ correeponding to a period 0.916 mecond, there were five sodal linos parallel to the buction 
of entrance ; while at the secti in wo had a perfect clapotis. Is ageinat this we observed the movement $=5, n=1$ (period $=0.907 \mathrm{a}$ ), which differe from the previous in that it has nodel lina right on the entrance section. Similor resulte wore observed for the ceses $(4,1),(1,4)$ and $(1,5)$, the first of the two rumbers in the brockets denotes the number of nodal lines perallel to the entruce of the port and the second donotas the number of nodel lines perallel to the leagth of the rave-camil.

To wore able to observe most of the cames corresponding to the characteriatic periode Ilsted. It must not, however, be assuad that the raterlovel at the pos itions carresponding to nodel lines was abeolutely stationary. Evidently in some cases thes had approciable movemont, but It was mall compared with the maximam amplitade.

The amplitudes of resonat movement ineide the part were very often double that of the incldent clapotis. In ane cases the ratio of mplitudes was as mach as three. This ahould give an idea of the importance of selohe provoked by a wave of small applitude. The amplitudes of oscillation ind ide the port were sasotimes as mach as $10 \mathrm{~cm}$, 1.e. ono-thind of the depth of water in the port.

\section{THEORETICLI PRESERTUTICA}

Te have formulated a theoretical analyais of the phenoman to take account of the complex agitation produced in the wave-canil in the vicinity of the port entrance.

The potential $\varnothing_{2}$ degcribing the motion in the wave camal will be taken the analytic continuation of the potential function $\varnothing_{1}$ of the resonant motion inside the port. We shall sappose as the boundary condition that at a great diatance in the canal from the port the potential $\bar{g}_{2}$ reduces to the potential function of a clepotis in a depth h :

$$
\Phi=C \sin \frac{2 \pi}{T} t \frac{\cos h[k(z+h)]}{\cos h k h} \cos k y
$$

1. in equation ( $(1)$, the potentials $\Phi_{1}$ and $\Phi_{2}$ define two runction $F_{1}$ and $F_{2}$, both satiofying the differential oquation (2). The fanction $F_{1}$ eatisfies the boundary condition (4) along the verticel will of the part; in place of (5) we have the new conditions:

$$
\frac{d F_{2}}{d n}=\frac{d F_{1}}{d n} \quad \text { for } y=0, x_{1}<x<x_{2} \text {, }
$$


along the entrance section. Equation (10) expresses the continaity of the normal derivative, which, however, is amall ince wo have in the port principally a resonant movemant. Again the equality of water levels at the common section gives us :

$$
F_{2}=F_{1} \quad \text { for } y=0 \quad x_{1} \leqslant x \leqslant x_{2}
$$

ainee the water-lovels are proportional to $F_{2}$ and $F_{1}$ in the rave-cenal and in the port respectively. The function $F_{1}$ io given by the sum of (6) and expression correaponding to the perturbation in the port :

$$
F_{1}=\sum_{m} A_{m} \cos \frac{m \pi x}{a} \cos \left\{\left(k^{2}-\frac{m^{2} \pi^{2}}{a^{2}}\right)^{1 / 2}(y-b)\right\}
$$

The coefficiente $A_{\mathrm{m}}$ carresponding to values of $\mathrm{n}$ other them that for the resonant movement are small. $F_{2}$ can be similarly written as a Fourier ceriea:

$$
\begin{aligned}
F_{2}= & \sum_{0}^{i<p k / \pi} c_{i} \cos \frac{i \pi}{p}\left(x-x_{1}\right) \cos \left\{\sqrt{k^{2}-\frac{i^{2} \pi^{2}}{p^{2}}} y+t_{i}\right\} \\
& +\sum_{i<p k / \pi} c_{i} \cos \frac{i \pi}{p}\left(x-x_{1}\right) e^{\sqrt{i^{2} \pi^{2} / p^{2}-k^{2} y}}
\end{aligned}
$$

where for brevity we have written $p=x_{2}-I_{1}$; the constente $C_{1}, E_{1}$ and $\Lambda_{1}$ can be determined with a safficient approximation by means of the conditions (10) and (II). Obviously in the canil the principal term corresponding to the generating clapotis is predominent. This term corresponds to $i=$ o in expreseion (1 3). The importanoe of other terms depende on the perturbation introduced in the part as also from the modifications of the elepotis in the canal.

Deteciled results of calculatione for the resonent and non-resonent cases $\mathrm{WII}$ be pablished later along with a comparison of experimental date.

Wo mas note that the form of the potantial ranction $F_{2}$ explains thearetically the tranowereal phenome obererved inthe canal in the vicinity of the entrame. This phenomonon is provoled by the reaction of the movement inside the port and attematen as wo go farther from the section of entrance. 


\section{corcinsIax}

Wo y not the practical, theoretical and experimatal empects of the stady. is regarde the practioal nature of the experimente, it in

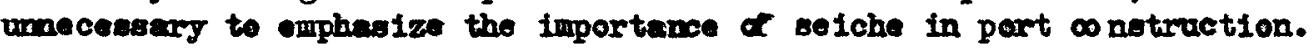
The study is hoped to be of use in model tochnique and particularly for the effocts of scalo-distertion.

To remane the theoretical and experimental aspects: The theory of Professers Kravtchenko and Kcilown is applicable when the profile of the water exurface at the ctrance of the port can be approximated by a horizontal straight line. This condition, however, linits on the one hand the with of the entrance section and on the other hend, it excludes resonant movewents with nodal lines terminating on the entrance.

In genaral the lew of resonance holda when the peried of the wea werve coinetdes with a characteristic pertod of the port basin. Wo have extended the range of frequencies so as to remowe the restriction on nodel lines mentioned above. The theoretical problem reduces to solving the Hecuman problex fer the differential equation $\Delta F+k^{2} F=0$, for a polygonal contorar.

\section{RERPRRBICES}

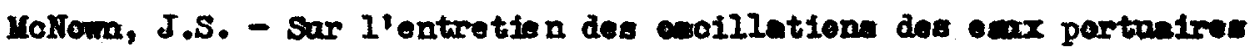
woun I'action de la bente in : Thesis, Oniveratity of Crenoble, I95I. (Pablication sclentifiquas ot technigess du Ministere de l'lis, Parie).

Krevtchenke, J. and Molfown, J.S. - Seich in Hectangulare Perte 8 Quarterly of Eppl. Math., 1954. (Under prens).

Kravtchanke, J. - Sar In théorie des ports rectangulairea a profonderur conetante : Comptes Rendue de l'Lcadénte des Scloncen, Parie, Tome 236. 


\section{RESUME}

\section{OSCILLATIONS A POR TUAIRES}

A. S. Apte et C. Marcou

Dang sa thèse, J. Mc Nown a étudié les oscillationo de la aurface Iibro des eax portuaires sous l'action de la houle venant du large. Nous rappelone que l'étude a été pourøuivie sur un modele réduit et idéalisé, I'ouvrage Gtait a fond horizontal et a parois verticales percios d'une passe étroite a borda verticaux. Ie modèle était placé dans un canal a houle beauc aup plus large, a fond horizental. Des pleges d'amortissement étaient disposés à l'amont du modèle. Rappelons les conclusions essers tiellea du trevail de lic Nown.

On observe dans le port un mouvement résonnant chaque fois que la p riede de la houle génératrice cošncide avec colle d'ane seiche propre du port, muppoes ferm6. Io mouvement des caux a l'intérieur du port peut tour joure tre détermint a priori af l'on connalt le mouvement de e eava a l'extérieur du port et dans le volsinage immédiat de la passe. Ce dernier mouvement se réduit à un clapotis placé dans lo voisinage de l'entrée.

Une théorie, dae à J. Kravtchenko ot J. Mc Nown permet, a partir do ces loie, de calculor le phénomène dano les cas particuliers ou le conteurs du port présente des formes simples (cercle, rectangle, otc...). Toutefois, Ne Nown a signalé des régines orratiques oì sa thèse est en défaut. Nous ovene repris la question on operant sur un modèle de port rectangulaire - xcité par la houle qui se propage dans un canal débouchant directement dans lo port et de largeur égale a celle de la passe. On s'écarte ainsi des conditions naturelles; mais le phénomène devient plus pur.

Nos principales conclusions peuvent être, a titre provisoire, résamées comme il suit. La lo1 de résonnance énoncée par Mc Hown, demeure exacte dans tous les cas que nous avons observes. Niais la loi du alapotis a l'ontré. ne s'est trauvé justifié pour les périodes résonnantes que si axane nodal. de la seiche propre du port n'aboutit a la passe.

Ia déternination de la surface libre des eax portuaires oxige alors 2. recours à d'autres règles plus compliqués.

Par contre, dans lo cas non récunnants, l'hypothèse da clapotis se trouve tro bien vérifié on premièr approximation. Les méthodes de caleul de Kravtchenko et Ne Nom a'appliquent intégralement ; nous indiquons quelques variantes simplificatrices de leur processus optratoire et nous comparone nos prérisions theqriques avec les mestres faites en laboratoiro. 